The Open Petroleum Engineering
CrossMark
Content list available at: www.benthamopen.com/TOPEJ/
DOI: $10.2174 / 1874834101609160216$

RESEARCH ARTICLE

\title{
Deep Plugging Experiments Study in High Temperature and Salinity Heterogeneous Clastic Reservoir
}

\author{
Jiwei Wang*, Kaoping Song and Qianru Li \\ Key Laboratory of Enhanced Oil Recovery, Ministry of Education, Northeast Petroleum University, Daqing, \\ Heilongjiang, 163318, China
}

\begin{abstract}
According to the exploration and field test results, the reservoir presents high temperature $\left(96^{\circ} \mathrm{C}\right)$ and high salinity $(77954.03 \mathrm{mg} / \mathrm{L})$ features; therefore, it is necessary to find proper plugging agent that can be used in these reservoirs to enhance oil recovery. In this paper, three kinds of polymers are studied and high temperature resistance as well as relative parameters are tested. According to the testing results, we make a preliminary determination that concentration of polymer solution is $2500-3500 \mathrm{mg} / \mathrm{L}$. However, due to the high reservoir temperature, APP5 polymer degrades severely. In view of the polymer degradation problem in high temperature, $2.7 \%$ chromium acetate is added into the APP5 solution $\left(\mathrm{Cr}^{3+} / \mathrm{APP} 5=1 / 60\right)$, and the retarder is added at the same time. The stability of this new plugging agent is then tested. The results show that, when the shearing time reaches $60 \mathrm{~s}$, plugging agent remains at a high level of $24600 \mathrm{mPa} \bullet \mathrm{s}$, and the static adsorption of APP5 remains at a low level of $0.36-0.38 \mathrm{mg} / \mathrm{g}$. As a consequence, the $\mathrm{Cr}^{3+}$ /APP5 plugging agent can meet the production requirements in reservoirs. Based on results of laboratory physical simulation experiment, plugging efficiency of this plugging agent is higher than $75 \%$, and injected slug $\operatorname{size}^{\mathrm{o}} \mathrm{O} \mathrm{Cr}^{3+} / \mathrm{APP} 5$ plugging agent is $0.3 \mathrm{PV}$.
\end{abstract}

Keywords: High temperature, High salinity, Injection pattern, Plugging agent, Plugging efficiency, Viscosity.

\section{INTRODUCTION}

In object block, the main source bed and reservoir is Cretaceous formation. Cretaceous formation is composed of three groups: Hollin, Napo and Tena. Napo group sandstone is the most important reservoir in southern basin, which includes four sections, including T, U, M2 and M1 sandstone buried from bottom to top respectively. U and M1 sandstones are the main oil-bearing layers $[1,2]$. Basin reservoir has the features of good physics. The number of sand layer is little, which has no obvious interlayer, and is mainly positive rhythm. The average net-to-gross ratio of the sandstone is $85 \%$, and the average porosity of the sandstone formation is $18.3 \%$.

The gas phase permeability of this formation is $3.22-1516.7 \times 10^{-3} \mu \mathrm{m}^{2}$, and the heterogeneity of this formation is significant. The viscosity of the underground crude oil is $11.5 \mathrm{mPa} \cdot \mathrm{s}$. According to testing results, the bubble point pressure is $2.1-5.52 \mathrm{MPa}$ and the average formation-saturation pressure difference is $19.4-28.1 \mathrm{MPa}$, which are both relatively large. The total salinity of formation water is $77954.03 \mathrm{mg} / \mathrm{L}$, and reservoir temperature is $96^{\circ} \mathrm{C}$. It therefore approximately can be categorized as medium-hole, medium-high permeability, high salinity and high temperature heterogeneous clastic reservoir.

The block has been developed since 1993. In February 2006, it got into the middle aqueous phase. Then the water cut has maintained at a high rising rate. By the end of March 2009, the average water cut of this region was up to $75.5 \%$, rising $21.1 \%$ compared with the water cut in February 2006. Along with the oilfield development, the rising of

\footnotetext{
* Address correspondence to this author at the School of Petroleum Engineering, Northeast Petroleum University, Daqing, 163318, China; Tel: +8604596506789; E-mails: wangjiwei2008@163.com,skp2001@sina.com
} 
water cut in most regions of the basin increased year by year, and the interlayer contradictions were more obvious. Therefore, we must take the plugging measures as soon as possible.

\section{SELECTION OF POLYMER TYPE}

From the macro level, polymer expands the swept volume mainly by increasing the viscosity of displacing fluid, reducing the displacement fluid and displacing fluid mobility ratio [3, 4] from the micro level, polymer improves the micro washing oil efficiency mainly due to its inherent viscoelasticity and increases the carrying capacity in the process of the flow $[5,6]$. Therefore, the factors affect the polymer viscosity, such as solid content, molecular weight, degree of hydrolysis, insoluble content, coefficient of screen mesh, filter factor and other important parameters. Reviewing the experience conclusions [7], it can be concluded that when the median of the reservoir pore radius is 5 times greater than the gyro-radius of the polymer molecule, blocking phenomenon will not occur. In addition, we have combined the specific conditions of the reservoir of high temperature, high salinity with domestic existing polymer products. We choose hydrophobic associating polymer (APP5) produced by Sichuan Guangya Polymer Chemical Industry Limited Company, which is similar to HPAM, but it is in network structure with high temperature and salt resistance monomer and has ultra-high molecular weight. Daqing salt-resistant polymer (KYPAM), produced by Petro-China Daqing Petrochemical Company, is salt resistance comb HPAM. HDSJ polymer, produced by Bejing Huading Hongji Petroleum Technology Limited Company, is temperature and salt resistance HPAM. Results of Polymer physics and chemistry performance test are shown in Table 1 [8].

Table 1. Polymer physics and chemistry performance test results.

\begin{tabular}{|c|c|c|c|}
\hline Polymer & APP5 & KYPAM & HDSJ \\
\hline Solid content $\%$ & 90.1 & 89.56 & 91.3 \\
\hline Molecular weight $\times 10^{4}$ & 3500 & 1646 & 2100 \\
\hline The degree of hydrolysis $\%$ & 18.2 & 23.2 & 25.1 \\
\hline Insoluble content $\%$ & 0.15 & 0.0992 & 0.01 \\
\hline Coefficient of screen mesh & 18.37 & 53.2 & 25.6 \\
\hline The filter factor & $>1.5$ & $>1.5$ & $>1.5$ \\
\hline
\end{tabular}

\section{LABORATORY TEST RESULTS AND ANALYSIS}

\subsection{The Viscosity Adaptability of Polymer Solution}

\subsubsection{The Setting of Theory Polymer Solution Viscosity Value Under the Formation Conditions}

Under the influence factors such as conveying manifold, well pattern, perforated well-bore and other mechanical shear and the formation minerals, biochemistry and oxygen degradation, viscosity empirical formula [9] is as follow:

$$
\mu \geq \frac{\mu_{1}}{(1-a)(1-b)}
$$

Where: $\mu$-the viscosity of the over ground polymer solution, $\mathrm{mPa} \cdot \mathrm{s}$.

$\mu_{1}$ - the viscosity of the underground crude oil, $\mathrm{mPa} \cdot \mathrm{s}$.

$a$ - viscosity loss percentage of polymer solution caused by delivery manifold, well pattern, perforation well-bore and other mechanical shear, $60 \%$ to $70 \%$.

$b$ - viscosity loss percentage of polymer solution caused by formation minerals, biochemistry and oxygen degradation, $50 \%$ to $65 \%$.

According to the viscosity of the underground crude oil, as well as the viscosity empirical formula (1), we can compute that the viscosity of polymer solution should not be less than $95.83 \mathrm{mPa} \cdot \mathrm{s}$.

\subsubsection{Thickening Property of Polymer Solution}

Materials: simulated formation water, formation sewage, APP5, KYPAM, HDSJ, thermostatic water-bath Brinell Digital Viscometer.

Methods: apply simulated formation water to make three kinds of polymer solution. Each kind of the polymer 
solution has 6 different concentrations: 1000mg/L, $1500 \mathrm{mg} / \mathrm{L}, 2000 \mathrm{mg} / \mathrm{L}, 2500 \mathrm{mg} / \mathrm{L}, 3000 \mathrm{mg} / \mathrm{L}, 3500 \mathrm{mg} / \mathrm{L}, 4000$ $\mathrm{mg} / \mathrm{L}$. Under the temperature of $96{ }^{\circ} \mathrm{C}$, measure viscosity of different polymer solutions with thermostatic water-bath Brinell Digital Viscometer DV-III. Measured results are shown in Fig. (1).

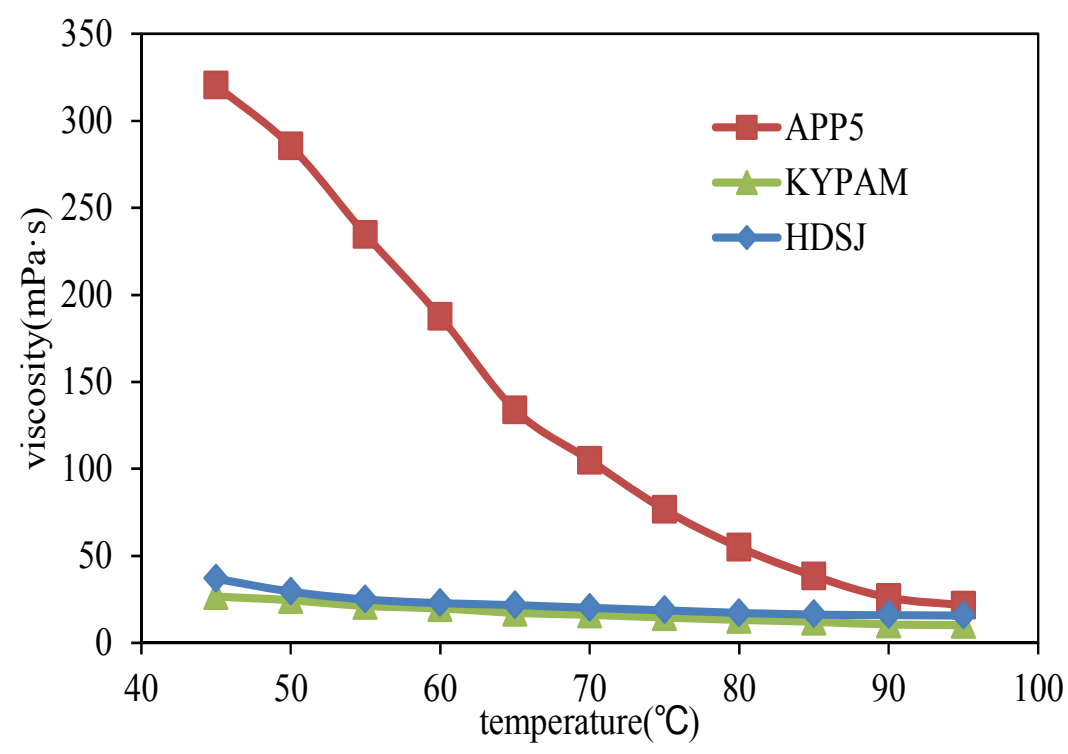

Fig. (1). The relationship between viscosity and concentration.

It can be seen from Fig. (1): Under the condition of same temperature $\left(96^{\circ} \mathrm{C}\right)$, as the concentration of polymer solution increases, the viscosity of the three kinds of polymer solutions also increases. Viscosity of APP5 is significantly higher than the other two kinds of polymer solution, and the viscosity value satisfies the theoretic requirement. Combined with the reservoir conditions, we make a preliminary determination that concentration of polymer solution is $2500-3500 \mathrm{mg} / \mathrm{L}$. We will then study the gel, which can improve viscosity of polymer solution.

\subsection{The Temperature-resistance of Polymer Solution}

Temperature is a critical parameter which influences the viscosity of polymer solution. the relationship between temperature and viscosity in line with the Arrhenius equation is as follow [10]:

$$
\mu(T)=A \exp \left(\frac{E_{a}}{R T}\right)
$$

Where: $\mu(T)$ : the viscosity of polymer solution under a given temperature.

A: parameter, depending on the concentration of polymer solution, solvent properties, polymer molecular weight, molecular structure and the shear rate etc.

Ea: the energy of flow activation.

R: constant.

$\mathrm{T}$ : thermodynamic temperature.

Materials: simulated formation water, formation sewage, APP5, KYPAM, HDSJ, thermostatic water-bath Brinell Digital Viscometer.

Methods: formulate solutions of the three kinds of polymers, whose concentration is $2500 \mathrm{mg} / \mathrm{L}$; measure the changes of viscosity of three kinds of polymer solutions while the temperature rises. The measuring results are shown in Fig. (2). 


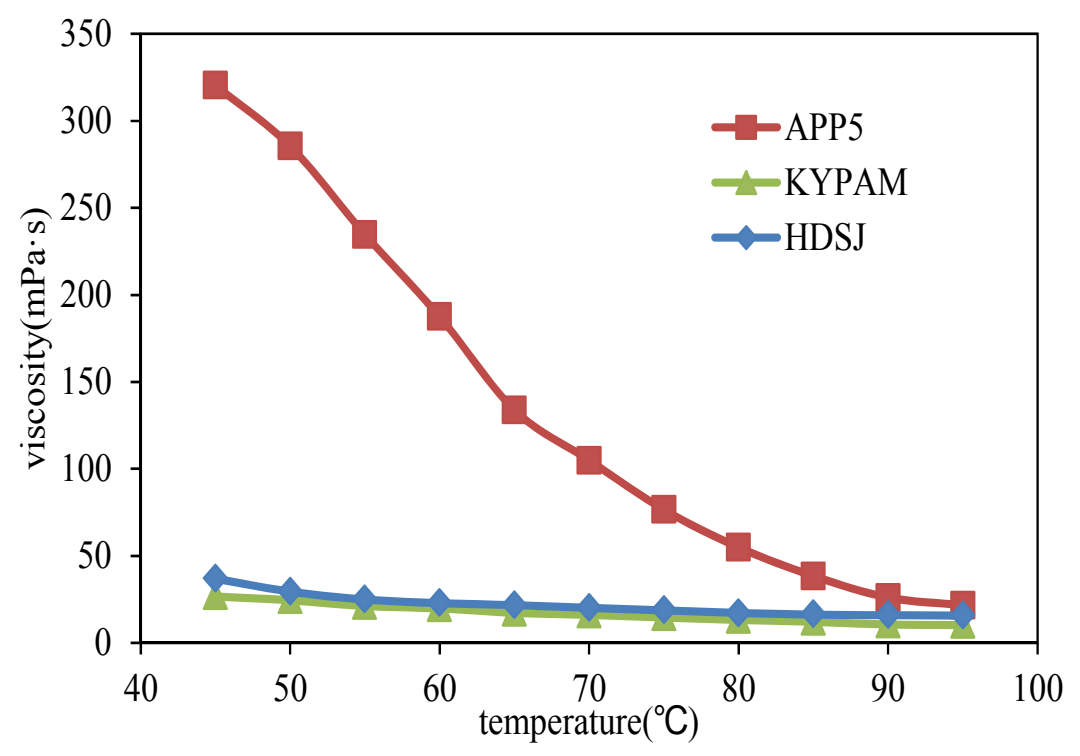

Fig. (2). The relationship between viscosity and temperature.

From the changing trend of the curve in Fig. (2), combined with the formula (2), it shows that given the same kinds of polymer solution at the same concentration, A and Ea are identical. Viscosity of the three kinds of polymer solutions decreases as temperature increases. The reduction amplitude of APP5 is the maximum. When temperature rises to 96 ${ }^{\circ} \mathrm{C}$, for different kinds of polymer solution, A and Ea are different. Measured viscosity of polymer solutions is also different. The viscosity order from high to low of the three polymer solutions is: APP5, HDSJ, KYPAM. Viscosities of solution are all lower than the theoretical values.

\subsection{Stability of the Polymer Solution}

After polymer solution is injected into formation, it's affected by calcium and magnesium ions, bacteria, and oxygen degradation effect. And it's mainly affected by reservoir function of high temperature thermal degradation.

Materials: simulated formation water, formation sewage, APP5, KYPAM, HDSJ, thermostatic water-bath Brinell Digital Viscometer, KD-II type thermostat.

Methods: simulate reservoir temperature $\left(96^{\circ} \mathrm{C}\right)$, salinity $(77954.03 \mathrm{mg} / \mathrm{L})$, bacteria and oxygen content (formation sewage from the object reservoir) through laboratory experiment; compound three kinds of polymer solution whose concentration is $2500 \mathrm{mg} / \mathrm{L}$. At the same time, measure viscosity of three kinds of polymer solution during each stage. The measured results are shown in Table 2. Retention rate is the ratio of the viscosity in last time and initial time.

Table 2. The stability of the polymer solution measure results.

\begin{tabular}{|c|c|c|c|c|c|c|c|}
\hline \multirow{2}{*}{ Polymer } & \multicolumn{9}{|c|}{ Viscosity (mPa·s) } & \multirow{2}{*}{ Retention rate (\%) } \\
\cline { 2 - 7 } & $\mathbf{0}$ & $\mathbf{1 2 h}$ & $\mathbf{2 4 h}$ & $\mathbf{3 6 h}$ & $\mathbf{4 8 h}$ & $\mathbf{6 0 h}$ & 14.13 \\
\hline APP5 & 36.1 & 18.2 & 9.3 & 6.5 & 5.2 & 5.1 & 19.83 \\
\hline KYPAM & 17.4 & 6.8 & 4.83 & 4.3 & 3.87 & 3.45 & 8.38 \\
\hline HDSJ & 17.3 & 5.4 & 2.3 & 1.75 & 1.56 & 1.45 & \\
\hline
\end{tabular}

In the high temperature and high salinity oil reservoir, hot oxygen degradation reaction of the polymer follows free radicals function [11]. Reaction can be represented as:

$$
\begin{gathered}
\mathrm{P}-\mathrm{H}+\mathrm{O}_{2} \rightarrow \mathrm{P}-+\mathrm{HOO}^{-} \\
\mathrm{P}-+\mathrm{O}_{2} \rightarrow \mathrm{POO}- \\
\mathrm{POO}-+\mathrm{P}-\mathrm{H} \rightarrow \mathrm{POOH}+\mathrm{P}-
\end{gathered}
$$


Polymer decomposition leads viscosity of the three kinds of polymer solution to decrease rapidly and viscosity retention rate are generally low.

\subsection{The Static Adsorption of the Polymer Solution}

Materials: simulated formation water, formation sewage, APP5, formation sand, thermostatic water-bath Brinell Digital Viscometer, KD-II type thermostat, centrifuge.

Methods: compound solutions of the APP5 polymer, whose concentration is $1500 \mathrm{mg} / \mathrm{L}$ and $3000 \mathrm{mg} / \mathrm{L}$ respectively. And the ratio of APP5 polymer solution to formation sand is 5:1; put those solution into $96^{\circ} \mathrm{C} \mathrm{KD}-\mathrm{II}$ type thermostat for a whole day, then separate solution with centrifuge and measure the concentration of APP5 polymer with titration.

The influence of formation sand on the static adsorption is shown in Table $\mathbf{3}$ :

Table 3. Static adsorption test results of APP5.

\begin{tabular}{|c|c|c|}
\hline & $\mathbf{1 5 0 0} \mathbf{m g} / \mathbf{L}$ & $\mathbf{3 0 0 0} \mathbf{m g} / \mathbf{L}$ \\
\hline The first test & 0.311 & 0.368 \\
\hline The second test & 0.306 & 0.373 \\
\hline The third test & 0.316 & 0.364 \\
\hline
\end{tabular}

According to Table 3, the static adsorption of APP5 (with concentration $1500 \mathrm{mg} / \mathrm{L}$ ) is about $0.3-0.32 \mathrm{mg} / \mathrm{g}$, and when the concentration of APP5 reaches $3000 \mathrm{mg} / \mathrm{L}$, the static adsorption is $0.36-0.38 \mathrm{mg} / \mathrm{g}$. The static adsorption of APP5 remains at a low level, so that the production requirements can be met.

\subsection{Stability of $\mathrm{Cr}^{3+} /$ APP5 Plugging Agent}

From above analysis, in view of special conditions of the reservoir with high temperature, high salinity, conventional single polymer can hardly satisfy actual needs, especially in the area of the long-term stability of the polymer solution. $\mathrm{Cr}^{3+}$ can combine with the hydroxy of polymer, forming ol bridge, and then forming a network structure with high stability [12]. The reaction can be expressed as follows:

$$
C_{r}^{3+}+P O O-\rightarrow C_{r}^{3+} / A P P 5 \text { plugging agent }
$$

Materials: simulated formation water, formation sewage, APP5, KYPAM, HDSJ, retarder, chromium acetate, thermostatic water-bath Brinell Digital Viscometer, KD-II type thermostat.

Methods: under the condition where the polymer chromium ratio is $60: 1$, prepare $2500 \mathrm{mg} / \mathrm{L}$ three kinds of plugging agent respectively. Adding $200 \mathrm{mg}$ retarder into per liter of plugging agent. Put them in $96{ }^{\circ} \mathrm{C}$ thermostat. At the same time, measure the viscosity of the three plugging agent during each stage. Measured results are shown in Fig. (3).

From Fig. (3) we can conclude that viscosity of the three plugging agent show stability after 60 days. The value from large to small in turn is: $\mathrm{Cr}^{3+} / \mathrm{APP} 5$ plugging agent, $\mathrm{Cr}^{3+} / \mathrm{KYPAM}$ plugging agent and $\mathrm{Cr}^{3+} / \mathrm{HDSJ}$ plugging agent. Sustained viscosity of $\mathrm{Cr}^{3+} / \mathrm{APP} 5$ plugging agent is about $110 \mathrm{mPa} \cdot \mathrm{s}$, which conforms to the requirements of the theoretical viscosity (formula 1 ).

\subsection{The Anti-shear Ability of $\mathrm{Cr}^{3+} /$ APP5 Plugging Agent}

Materials: simulated formation water, formation sewage, APP5, chromium acetate, thermostatic water-bath Brinell Digital Viscometer, KD-II type thermostat.

Methods: under the condition where the polymer chromium ratio is 60:1, prepare /APP5 plugging agent of which the concentration is $1500 \mathrm{mg} / \mathrm{L}$. Put them in $96{ }^{\circ} \mathrm{C}$ thermostat after several seconds shear. At the same time, measure viscosity of the /APP5 plugging agent during each stage. 


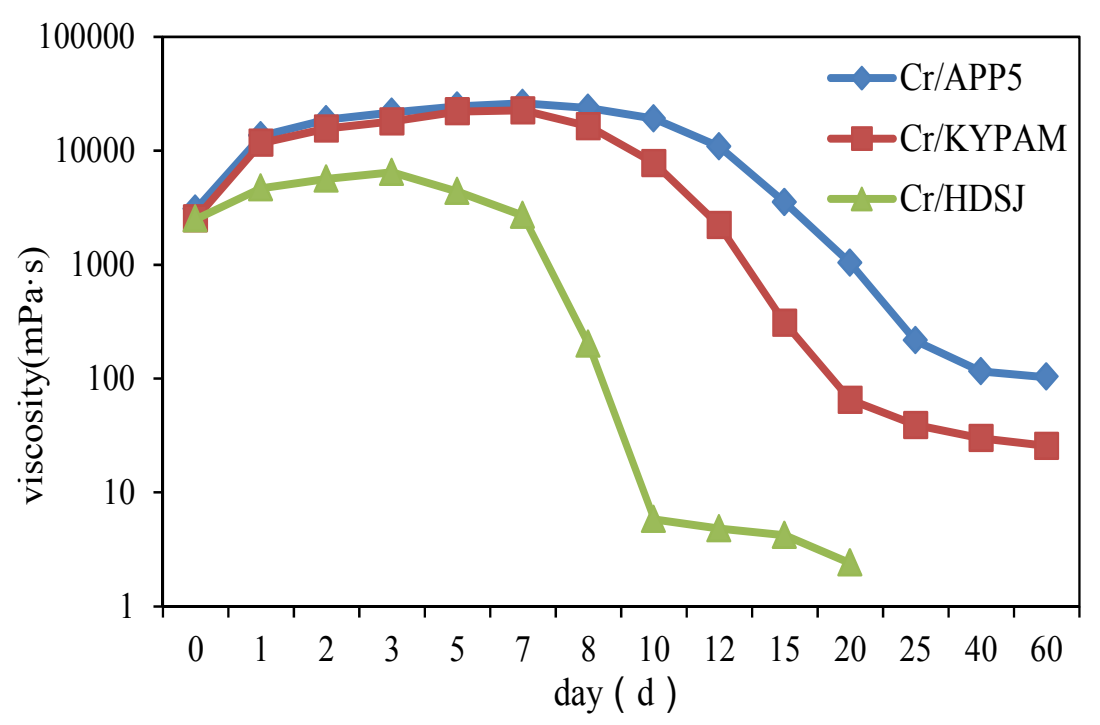

Fig. (3). Plugging agent stability test.

The anti-shear ability of /APP5 plugging agent is shown in Table 4:

Table 4. Influence of mechanical shearing force on plugging agent.

\begin{tabular}{|c|c|c|}
\hline $\begin{array}{c}\text { Shearing time } \\
\mathbf{s}\end{array}$ & $\begin{array}{c}\text { Gelling time } \\
\mathbf{h}\end{array}$ & $\begin{array}{c}\text { Gel strength } \\
\mathbf{m P a} \cdot \mathbf{s}\end{array}$ \\
\hline 0 & 15 & 35400 \\
\hline 30 & 14 & 29700 \\
\hline 60 & 14 & 24600 \\
\hline
\end{tabular}

As can be seen from Table 4, the influence of mechanical shearing force on gelling time can be ignored, and with the increasing of shearing time, the plugging agent strength keeps decreasing; however, plugging agent strength remains at a high level when the shearing time reaches 60s. Obviously, the mechanical shearing resistance ability of this /APP5 plugging agent is high.

\section{RESULTS AND ANALYSIS OF SIMULATED OIL DISPLACEMENT EXPERIMENT}

\subsection{Experimental Materials and Conditions}

Experiment materials and methods:

Three kinds of polymer: APP5, KYPAM, HDSJ;

Chromium acetate (mass fraction 2.7\%), retarder

Water salinity of simulated formation: $77954.03 \mathrm{mg} / \mathrm{L}$.

Each kind of ion content is shown in Table 5.

Table 5. Ions content in detail.

\begin{tabular}{|c|c|c|c|c|c|c|}
\hline \multicolumn{6}{|c|}{ Ion content $(\mathrm{mg} / \mathrm{L})$} & \multirow{2}{*}{ Total mineralization $(\mathrm{mg} / \mathrm{L})$} \\
\hline $\mathrm{Na}^{+}, \mathrm{K}^{+}$ & $\mathbf{M g}^{2+}$ & $\mathrm{Ca}^{2+}$ & $\mathrm{Cl}^{-}$ & $\mathrm{SO}_{4}{ }^{2-}$ & $\mathrm{HCO}_{3}^{-}$ & \\
\hline 61188.37 & 1282.5 & 7159.5 & 77341.34 & 118.33 & 494.36 & 77954.03 \\
\hline
\end{tabular}

Formation sewage: from the object reservoir.

Cores used in experiment: cleaned natural columnar cores $\Phi 24 \mathrm{~mm} \times 10 \mathrm{~cm}$.

Porosity: $15-20 \%$. 
Air permeability: $1000-1200 \times 10^{-3} \mu^{2}$.

Laboratory simulated temperature: constant temperature $96^{\circ} \mathrm{C}$.

\subsection{Experimental Results and Analysis}

\subsubsection{The Plugging Capacity of $\mathrm{Cr}^{3+} / \mathrm{APP}$ Plugging Agent}

The plugging capacity of plugging agent is usually expressed by plugging efficiency. Plugging efficiency refers to the ability of water through the porous medium before and after the plugging agent is injected. The calculation formula is shown as follow:

$$
\eta=\left(1-\frac{K_{a}}{K_{b}}\right) \times 100 \%
$$

Where: $\eta$ - plugging efficiency

$K_{a}$ - permeability to water before plugging agent injection

$K_{b}$ - permeability to water after plugging agent injection

Methods: water flooding+0.3PV $\mathrm{Cr}^{3+} / \mathrm{APP} 5$ plugging agent + water flooding.

The plugging capacity of $\mathrm{Cr}^{3+} / \mathrm{APP} 5$ plugging agent is shown in Table 6.

Table 6. The plugging capacity of $\mathrm{Cr}^{3+} / \mathrm{APP} 5$ plugging agent.

\begin{tabular}{|c|c|c|c|c|c|}
\hline \multirow{2}{*}{ Number } & \multirow{2}{*}{ Plugging agent state } & \multirow{2}{*}{$\begin{array}{c}\text { Injected volume } \\
\text { PV } \\
\end{array}$} & \multicolumn{2}{|c|}{ Permeability to water $\left(10^{-3} \mu \mathrm{m}^{2}\right)$} & \multirow{2}{*}{$\begin{array}{c}\text { Plugging efficiency } \\
\% \\
\end{array}$} \\
\hline & & & $\mathbf{K}_{\mathrm{a}}$ & $\mathbf{K}_{\mathbf{b}}$ & \\
\hline 1 & \multirow{2}{*}{ New } & 0.3 & 1019 & 127 & 87.53 \\
\hline 2 & & 0.3 & 1052 & 119 & 88.69 \\
\hline 3 & \multirow{2}{*}{ After 30 days } & 0.3 & 1147 & 247 & 78.46 \\
\hline 4 & & 0.3 & 1773 & 401 & 77.38 \\
\hline
\end{tabular}

As is shown in Table 6, the plugging efficiency of this plugging agent is higher than $75 \%$ in reservoirs with high permeability, so that the plugging capacity of $\mathrm{Cr}^{3+}$ /APP5 plugging agent will meet the field production requirements, while it maybe damage the reservior to some extent.

\subsubsection{Relationship Between Injected Quantity of $\mathrm{Cr}^{3+} /$ APP5 Plugging Agent and Recovery Efficiency}

Methods: water flooding $90 \%+\mathrm{Cr}^{3+} / \mathrm{APP} 5$ plugging agent + water flooding $98 \%$.

When the injected PV numbers are different, $\mathrm{Cr}^{3+}$ /APP5 plugging agent oil displacement experiment results are shown in Table 7.

Table 7. Relationship between injected PV of $\mathrm{Cr}^{3+} / \mathrm{APP} 5$ plugging agent and recovery efficiency.

\begin{tabular}{|c|c|c|c|}
\hline \multirow{2}{*}{ Experimental scheme } & \multicolumn{2}{|c|}{ Recovery efficiency (\%) } & \multirow{2}{*}{$\begin{array}{c}\text { The added value of } \\
\text { recovery efficiency (\%) } \\
\begin{array}{c}\text { Compared with Early } \\
\text { water flooding }\end{array} \\
\end{array}$} \\
\hline & $\begin{array}{l}\text { Early water } \\
\text { flooding }\end{array}$ & $\begin{array}{l}\text { Subsequent water } \\
\text { flooding }\end{array}$ & \\
\hline $\begin{array}{c}\text { Water flooding } 90 \%+0.1 \mathrm{PV} \mathrm{Cr}^{3+} / \mathrm{APP} 5 \text { plugging agent }+ \text { Water } \\
\text { flooding } 98 \%\end{array}$ & 43.5 & 56.1 & 12.6 \\
\hline $\begin{array}{c}\text { Water flooding } 90 \%+0.2 \mathrm{PV} \mathrm{Cr}^{3+} / \mathrm{APP} 5 \text { plugging agent }+ \text { Water } \\
\text { flooding } 98 \%\end{array}$ & 44.6 & 58.4 & 13.8 \\
\hline $\begin{array}{c}\text { Water flooding } 90 \%+0.3 \mathrm{PV} \mathrm{Cr}^{3+} / \mathrm{APP} 5 \text { plugging agent }+ \text { Water } \\
\text { flooding } 98 \%\end{array}$ & 44 & 60.9 & 16.9 \\
\hline $\begin{array}{c}\text { Water flooding } 90 \%+0.4 \mathrm{PV} \mathrm{Cr}^{3+} / \mathrm{APP} 5 \text { plugging agent }+ \text { Water } \\
\text { flooding } 98 \%\end{array}$ & 43.6 & 61.2 & 17.6 \\
\hline
\end{tabular}

From Table 7 we can conclude that the subsequent water flooding increases along with the increase of plugging agent PV numbers, while the economic cost also rises, because the cost of $\mathrm{Cr}^{3+} / \mathrm{APP} 5$ is high. The increasing width of 
subsequent water flooding from $0.3 \mathrm{PV}$ to $0.4 \mathrm{PV}$ is less than that subsequent water flooding from $0.2 \mathrm{PV}$ to $0.3 \mathrm{PV}$. Besides, injection of $\mathrm{Cr}^{3+}$ /APP5 becomes more difficult with the PV numbers of plugging agent increases. It will damage formation and the equipment at the high pressure injecting process. So we select $0.3 \mathrm{PV}$, which will render the best economic benefit.

\subsubsection{Relationship Between Injected Time of $\mathrm{Cr}^{3+} / A P P 5$ Plugging Agent and Recovery Efficiency}

Methods: water flooding $+0.3 \mathrm{PV} \mathrm{Cr}^{3+} / \mathrm{APP} 5$ plugging agent + water flooding $98 \%$.

Choose different degree of water drive recovery efficiency, inject $0.3 \mathrm{PV} \mathrm{Cr}^{3+} / \mathrm{APP} 5$ plugging agent, which is selected from Table 7. Oil displacement experiment results are shown in Table $\mathbf{8}$.

Table 8. Relationship between injected time of $\mathrm{Cr}^{3+} / \mathrm{APP} 5$ plugging agent and recovery efficiency.

\begin{tabular}{|c|c|c|c|}
\hline \multirow{2}{*}{ Experimental scheme } & \multicolumn{2}{|c|}{ Recovery efficiency (\%) } & \multirow{2}{*}{\begin{tabular}{|c|}
$\begin{array}{c}\text { The added value of recovery } \\
\text { efficiency }(\%)\end{array}$ \\
$\begin{array}{c}\text { Compared with early water } \\
\text { flooding }\end{array}$
\end{tabular}} \\
\hline & \begin{tabular}{|c|} 
Early \\
water flooding
\end{tabular} & $\begin{array}{l}\text { Subsequent water } \\
\text { flooding }\end{array}$ & \\
\hline $\begin{array}{l}\text { Water flooding } 65 \%+0.3 \mathrm{PV} \mathrm{Cr}^{3+} / \mathrm{APP} 5 \text { plugging agent }+ \text { Water flooding } \\
98 \%\end{array}$ & 36.2 & 64.2 & 28 \\
\hline $\begin{array}{c}\text { Water flooding } 75 \%+0.3 \mathrm{PV} \mathrm{Cr}^{3+} / \mathrm{APP} 5 \text { plugging agent }+ \text { Water flooding } \\
98 \%\end{array}$ & 40.8 & 63.4 & 22.6 \\
\hline $\begin{array}{l}\text { Water flooding } 85 \%+0.3 \mathrm{PV} \mathrm{Cr}^{3+} / \mathrm{APP} 5 \text { plugging agent }+ \text { Water flooding } \\
98 \%\end{array}$ & 43.3 & 59.3 & 16 \\
\hline $\begin{array}{c}\text { Water flooding } 95 \%+0.3 \mathrm{PV} \mathrm{Cr}^{3+} / \mathrm{APP} 5 \text { plugging agent }+ \text { Water flooding } \\
98 \%\end{array}$ & 45.3 & 56.6 & 11.3 \\
\hline
\end{tabular}

From Table $\mathbf{8}$ we can conclude that the subsequent water flooding increases with the plugging agent injecting earlier, while the early water flooding reduces. At the same time, the economic cost rises. The reducing width of subsequent water flooding from early water flooding $65 \%$ to $75 \%$ is less than the early water flooding from $75 \%$ to $85 \%$. So we select early water flooding $75 \%$, which will render the best economic benefit.

\section{CONCLUSION}

- Due to the reservoir specific conditions of high temperature and high salinity, single polymer will be effected by the formation mineral, biological chemical and thermal oxygen degradation. It will lead to severe loss of polymer solution viscosity, failing meeting the theory requirement.

$\cdot \mathrm{Cr}^{3+}$ can combine with the hydroxy of polymer, form ol bridge, and turn into gel solution. Under the action of retarder, the plugging agent can form a network structure with high stability in a high temperature condition. From the plugging agent stability experiment, $\mathrm{Cr}^{3+}$ /APP5 plugging agent is able to meet the specific conditions of the reservoir.

-Through laboratory physical simulation experiment, we identify that injected slug size of $\mathrm{Cr}^{3+} / \mathrm{APP} 5$ plugging agent is $0.3 \mathrm{PV}$. When the early water flooding is $75 \%$, it will provide the best economic benefit.

\section{CONFLICT OF INTEREST}

The authors confirm that this article content has no conflict of interest.

\section{ACKNOWLEDGEMENTS}

This work is supported by National Science and Technology Major Project of China (No.2011ZX05052) and Northeast Petroleum University Innovation Foundation For Postgraduate (JSCX2016-007NEPU).

\section{REFERENCES}

[1] G.H. Lee, M.A. Eissa, C.L. Decker, J.P. Castagna, and D.J. Meara, "Aspects of the petroleum geology of the Bermejo field, northwestern Oriente Basin, Ecuador", J. Pet. Geol., vol. 27, pp. 335-356, 2004. [http://dx.doi.org/10.1111/j.1747-5457.2004.tb00062.x]

[2] A. Williamson, Rick, C. D. Xu, and M. Koop, "Quantitative interpretation of seismic facies-A case study, oriente basin ecuador", In: International Exposition \& SEG Annual Meeting, Dallas, Texas: USA, 1999, pp. 2452-2458.

[3] D. Wang, J.C. Cheng, and J.Z. Wu, "Application of polymer flooding technology in Daqing Oil-field", Acta. Petrolei. Sinica, vol. 26, pp. 
$74-78,2005$.

[4] Y.B. Lan, Q.Y. Yang, and B.H. Li, "Experimental research on sweep efficiency and oil-displacement efficiency of polymer flooding", Acta. Petrolei. Sinica, vol. 27, pp. 64-68, 2006.

[5] M.S. Kamal, A.S. Sultan, U.A. Mubaiyed, I.A. Hussien, and M. Pabon, "Evaluation of rheological and thermal properties of a new fluorocarbon surfactant-polymer system for EOR applications in high-temperature and high-salinity oil reservoirs", J. Surfactants Deterg., vol. 17, pp. 985-993, 2014.

[http://dx.doi.org/10.1007/s11743-014-1600-7]

[6] Z.T. Li, and L.W. Lake, The Science Foundation of Enhanced Oil Recovery, Petroleum Industry Press: Beijing, 1989.

[7] X. G. Lu, Theory and Practice of Enhanced Oil and Gas Recovery, Industry Press: Beijing Petroleum, 2011.

[8] A.R. Alhashmi, P.F. Luckham, J.Y. Heng, R.S. Almaamari, and A. Zaitoun, "Adsorption of high-molecular-weight EOR polymers on glass surfaces using AFM and QCM-D", Energy Fuels, vol. 27, pp. 2437-2444, 2013

[http://dx.doi.org/10.1021/ef302143a]

[9] A. Omari, G. Chauveteau, and R. Tabary, "Gelation of polymer solutions under shear flow", Colloids Surf. A. Physicochem. Eng. Aspects, vol. 225, pp. 37-48, 2003. [http://dx.doi.org/10.1016/S0927-7757(03)00319-4]

[10] U. Bianchi, and V. Magnasco, "The influence of temperature on the viscosity of polystyrene solutions", J. Polym. Sci, vol. 41, pp. 177-187, 1959.

[11] F.L. Zhao, Y.F. Wang, and C.L. Dai, "Improving of oil recovery technology after polymer flooding", J. China Univ. Petr, vol. 30, pp. 86-89, 2006.

[12] R. Li, W.F. Pu, and H. Peng, "Preparation and flooding properties of hyper-branched and associated polymers", J. Southwest Petr. Univ., vol. 37, pp. 145-152, 2015.

(C) Wang et al:; Licensee Bentham Open

This is an open access article licensed under the terms of the Creative Commons Attribution-Non-Commercial 4.0 International Public License (CC BY-NC 4.0) (https://creativecommons.org/licenses/by-nc/4.0/legalcode), which permits unrestricted, non-commercial use, distribution and reproduction in any medium, provided the work is properly cited. 